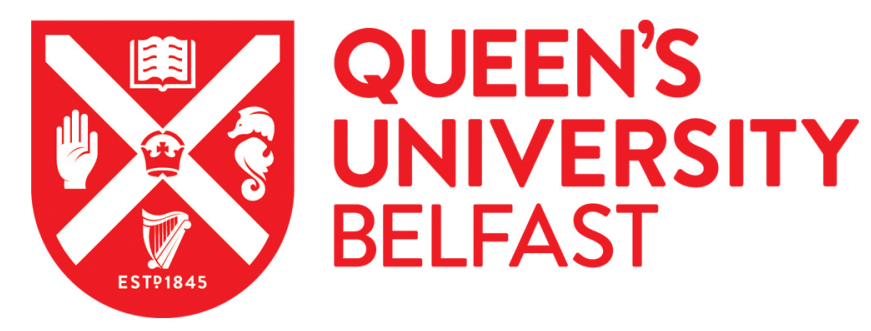

\title{
Integrated reporting, textual risk disclosure, and market value
}

Elshandidy, T., Elmassri, M., \& Elsayed, M. (2021). Integrated reporting, textual risk disclosure, and market value. Corporate Governance. https://doi.org/10.1108/CG-01-2021-0002

\section{Published in:}

Corporate Governance

\section{Document Version:}

Peer reviewed version

\section{Queen's University Belfast - Research Portal:}

Link to publication record in Queen's University Belfast Research Portal

\section{Publisher rights}

Copyright 2021 Emerald Publishing.

This work is made available online in accordance with the publisher's policies. Please refer to any applicable terms of use of the publisher.

\section{General rights}

Copyright for the publications made accessible via the Queen's University Belfast Research Portal is retained by the author(s) and / or other copyright owners and it is a condition of accessing these publications that users recognise and abide by the legal requirements associated with these rights.

Take down policy

The Research Portal is Queen's institutional repository that provides access to Queen's research output. Every effort has been made to ensure that content in the Research Portal does not infringe any person's rights, or applicable UK laws. If you discover content in the Research Portal that you believe breaches copyright or violates any law, please contact openaccess@qub.ac.uk. 


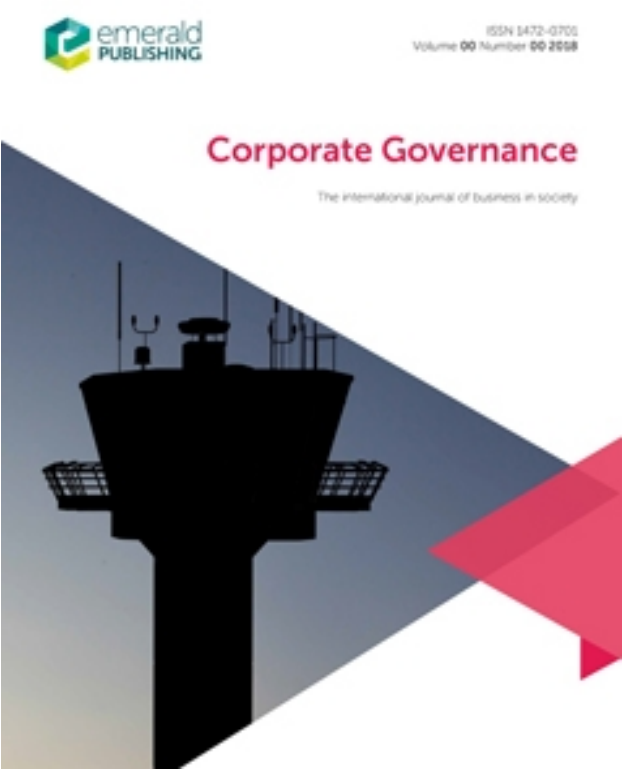

Integrated reporting, textual risk disclosure, and market value

\begin{tabular}{|r|l|}
\hline Journal: & Corporate Governance \\
\hline Manuscript ID & CG-01-2021-0002.R3 \\
\hline Manuscript Type: & Original Article \\
\hline Keywords: & $\begin{array}{l}\text { Integrated reporting, Textual risk disclosure, Market value, Institutional } \\
\text { theory }\end{array}$ \\
\hline
\end{tabular}

\section{SCHOLARONE \\ Manuscripts}




\title{
Integrated reporting, textual risk disclosure, and market value
}

\begin{abstract}
Purpose - Exploiting the mandatory provision of integrated reporting in South Africa, this paper investigates whether this regulatory switch from the conventional annual report is associated with differences in the level of textual risk disclosure (TRD). This paper also examines the economic usefulness of this regulatory change by observing the impact of TRD on the complying firms' market values.
\end{abstract}

Design/methodology/approach - Archival data are collected and examined employing timeseries difference design and difference-in-differences design.

Findings - We find that the level of TRD within the mandatory integrated reporting is significantly lower than that of annual reports. We find that the impact of TRD in integrated reporting on market value compared to that of annual reports is statistically not different from zero. Our further analyses suggest that corporate governance effectiveness is not a moderating factor to our results. Our results are robust to comparisons with the voluntary adoption of integrated reporting in the UK.

Originality/value - Collectively, our results suggest that managers' adherence to the mandatory provision of integrated reporting has significantly decreased the level of (voluntary) TRD they tended to convey within the conventional annual reports, resulting in a trivial impact on market value. These unintended consequences should be of interest to the International Integrated Reporting Council and other bodies interested in integrated reporting.

Keywords Integrated Reporting; Textual Risk Disclosure; Market Value, Institutional Theory

Paper type Research paper 


\section{Introduction and Research Background}

Integrated reporting (IR) has been presented as one of the main strategic management and accounting innovations in the last decade (De Villiers et al., 2014; Dumay et al., 2017; Vitolla et al., 2020; Hasoda, 2021) as a transitional reporting tool to make a leap from a promising concept to a powerful practice (Busco et al., 2013), and as the rational choice to face the reporting challenges (Adams, 2015; Serafeim, 2015). However, there is a group of studies that highlights the challenges and barriers in adopting IR and operationalising the IR framework elements, principles and objectives (Dumay et al., 2017). These challenges lead the production of ineffective IR (McNally et al., 2017). This leads some scholars to argue that IR is a temporary fad or a fashion (Brown and Dillard, 2014; Flower, 2015). These inconsistent arguments motivate us to investigate the effectiveness of the adoption of IR.

Therefore, our paper investigates whether the adoption of IR enhances corporate transparency. IR encourages organizations to increase the level of corporate disclosure through providing "information not currently subject to mandatory disclosure requirements" (International Integrated Reporting Council (IIRC), 2011, p.21). In order to achieve the holistic connectivity of IR, companies should release more information about corporate strategy and sustainability, including information about existing and potential business risks. "The Integrated Report should identify any real risks that could have extreme consequences, even though the probability of their occurrence might be considered quite small” (IIRC, 2011, p.15). As IR enhances transparency, investors can obtain more information in less time and at a lower cost, while being able to allocate their capital in a more efficient manner (Lee and Yeo, 2016).

We observe whether the level of corporate transparency is significantly changed when companies switch from the conventional form of annual reports (ARs) to IR. Especially, the principle-based IR framework gives a space of flexibility to companies to adopt IR, as there are many challenges to achieve a consistent adoption of IR disclosure (Morgan et al., 2009; Dumay et al., 2017). Arguably, we should not consider adoption of IR as a 'taken for granted' practice. 
However, the IR principles, elements and objectives should be empirically examined in order to evaluate the effectiveness of the IR adoption.

The existing evidence (e.g., Kothari et al., 2009; Cormier and Magnan, 2014; Leuz and Wysocki, 2016; Dyer et al., 2017; El-Diftar et al., 2017; Naheed et al., 2021) suggests that corporate disclosure, which covers several topics including, for example, forward-looking, corporate social responsibility, and risk, benefits companies as it improves corporate transparency and thus reduces information asymmetries. Based on prior literature (e.g., Linsley and Shrives, 2005), risk disclosure practises should result in improving corporate transparency. Furthermore, Kravet and Muslu (2013), Abraham and Shrives (2014), Campbell et al. (2014), and Elshandidy and Shrives (2016) find that in order to enhance corporate transparency companies should disclose information about firm-specific risks. Therefore, we use TRD as a proxy for corporate transparency. Unlike previous studies, we compare the level of TRD of IR in mandatory and voluntary settings. We choose South Africa, where IR is mandated and the UK where applying IR is voluntary. The rational of choosing those contexts is that as of today, IR is South Africa has taken the leading role in promoting IR. In 2009, Integrated Reporting Committee of South Africa (IRCSA) released the King III report, which introduced a holistic communication tool that "evolves around leadership, sustainability, and corporate citizenship ... ethical values of responsibility, accountability, fairness, and transparency" (Institute of Directors Southern Africa, 2009, p.10). Because the King Code is a Johannesburg Stock Exchange (JSE) listing requirement, listed firms were required to produce IRs for annual periods as a mandatory practise (Masegare and Ngoepe, 2018).

In addition, the UK has a significant contribution regarding IR practise. In 2009, Prince's Accounting for Sustainability (A4S) created a new connected and integrated reporting model to provide a coherent and complete picture of the organization. Then, in 2010 the A4S project and the Global Reporting Initiative (GRI) announced the formation of an IIRC to provide a comprehensive, concise, complete, clear and comparable format for corporate reporting. In 2013 the IIRC issued an international framework of IR, which contributes towards setting a globally 
accepted IR framework that brings together financial, environmental, social and governance information in a clear, concise, consistent and comparable format (IIRC, 2013). The underlying concepts and values of IR are the same in the South African and UK contexts. Both emphasise the connectivity between the corporate risks, strategy and sustainability to create value (IIRC, 2013).

Moreover, we examine the significance of IR in creating value. One of the main foundation objectives of IR is to create short, medium and long-term value for various stakeholders (IIRC, 2013). There is an ambiguity about the meaning of the value-creation concept, as the definition is quite vague (Dumay et al., 2017). The IIRC (2013, p. 33) defines value creation as "the process that results in increases, decreases or transformations of the capitals caused by the organisation's business activities and outputs". There are six capitals defined by the IR framework; financial, manufactured, intellectual, natural, human, social \& relationship. This study focuses on the financial capital and examines the value relevance of TRD on the firm value as one of the key business outputs. There is a stream of research (Lee and Yeo, 2016; Barth et al., 2017; Vitolla, et al., 2020; Wahl et al., 2020) that examines the effect of IR on firm value. Lee and Yeo (2016) using a sample of firms listed in JSE, found a positive relationship between firm value and IR quality. similarly, Barth et al. (2017) examine a sample of a listed companies in JSE and find a positive association between the firm value and IR quality. Inconsistently, Wahl et al. (2020, p.1), based on an international sample of listed companies that adopt IR voluntarily, find no significant effect of IR disclosure on the firm value. They argue that voluntary adopters might have a "relatively high level of transparency leading to an absent additional effect of IR disclosure. Positive effects of IR appear to be more relevant in environments where IR is mandatory."

Arguably, there are inconsistencies across the findings of the studies that examine the practicality of the IR framework. For instance, Albitar et al. (2020) find that adopting IR resulted in a positive and significant relationship between Environmental, Social and Governance (ESG) disclosure scores and firm performance. Equally, Guthrie et al. 2020) find that organizations used 
IR to disclose a broader group of risks, related to the environment and society. However, Mervelskemper and Streit (2017) reveal that the ESG performance is significantly valued and in a positive direction when companies release an ESG report, irrespective of its type either conventional report or IR. Therefore, we argue that it is worth extending prior literature by not only investigating the effectiveness of IR framework, but also exploring this effectiveness in different mandatory and voluntary settings such those in the South Africa and the UK, respectively.

Accordingly, we examine the IR transparency in both mandatory and voluntary settings, and the value relevance of TRD by observing its impact on the firm value. Our paper extends prior IR literature as most, if not all, of that literature focuses solely on either South African companies as a mandatory context (e.g., Moolman et al., 2016; Raemaekers et al., 2016) or international companies that adopt IR voluntarily (Guthrie et al., 2020). The benefits of IR of enhancing transparency might be different in a mandatory setting rather than the voluntary one. Companies within the mandatory IR regime have to disclose information based on the high standards of IR standard setting bodies (e.g., IRCSA). However, the firms that voluntarily choose to adopt IR might have much flexibility in terms of disclosing information. Wahi et al (2020) argue that the impact of IR on value creation is different between mandatory and voluntary settings. They argue that given the relatively new system of IR, there is still a need for more empirical evidence to verify the value relevance of IR, since most of the extant evidence considers mandatory settings (i.e., South Africa), and very little evidence is available to explore whether IR has value relevance in voluntary settings (i.e., UK). Therefore, we aim to empirically examine the effectiveness of IR in achieving two of its main objectives, through addressing these two research questions: Does the adoption of IR enhance corporate transparency in both mandatory and voluntary settings? and Do risks disclosed in IR create value to investors in both mandatory and voluntary settings?

In doing so, we manually collect 215 firm-year reports (144 IRs from 2011 to 2014 and 71 ARs from 2009 to 2010) of firms listed in the JSE of South Africa. This enables us to employ a 
time-series difference design controlling for endogeneity bias resulting from firm-level correlated omitted characteristics (Doyle and Magilke, 2013). The mandatory application enables us to examine: first, whether the level of TRD is significantly changed in IR (compared to AR); second, whether the 'transparency-market value' relationship is significantly changed in IR (compared to AR). Answering these research questions is important for IIRC (and other bodies interested in integrated reporting) to assess the consequences (outcomes and directions) of the IR standard on the corporate transparency practice and the impact on the firm value.

In addition, in order to examine the 'mandatory-voluntary' dichotomy, we hand collect 119 reports for UK firms, as their engagement in IR is entirely a voluntary decision. Our decision to expand our sample is motived by prior literature; for example, Girella, et al. (2020) find evidence that certain factors at both firm and country levels affect firm's decision on whether to adopt IR voluntarily. Importantly, since UK firms are reasonably counterfactual to South African companies, we are able to employ different examination techniques (e.g., difference-in-differences controlling for simultaneity and self-selection-based endogeneity concern; see, Carcello and Li, 2013; Leuz and Wysocki, 2016) and thus, illustrate our results' robustness.

In our examinations of the impact of adopting IR on the level of TRD, our time-series difference results suggest that the mandatory IR adoption regime (SA) is associated with a lower level of TRD. On the contrary, the evidence we find suggests that the voluntary IR adoption regime $(\mathrm{UK})$ is associated with a lower level of TRD. We obtain confirmatory findings from a difference-in-differences test that absorbs the net effect of IR mandatory adoption on TRD. Specifically, we find a strongly negative association between mandatory IR adoption and TRD. Next, we examine the impact of risk information conveyed during the mandatory adoption of IR on the firm's market value. Interestingly, we find that the impact of TRD on firm value in the period of IR relative to the impact before the IR adoption is not statistically significant. Collectively, given the lower level of TRD conveyed by managers after adopting IR, it seems that 
investors do not consider TRD as an important factor in evaluating the firm's value. Our further analyses suggest that corporate governance effectiveness is not a moderating factor to our results.

This study's contributions are twofold. First, this study explores the practical benefits of the IR regime through examining the effectiveness of IR in achieving its key objectives. Given the ongoing debate around whether IR has practical benefits or is just a fashionable reporting trend, we empirically test whether the IR regime enhances corporate transparency and creates value. This study moves the debate forward by not only studying the incentives of companies to enhance their corporate transparency in the adopted IR through TRD, but also examining whether or not such disclosure has an incremental value to stakeholders. Second, while most previous studies have considered only South African firms in a mandatory setting, and other studies examine international firms in a voluntary setting, we complement existing literature by comparing how IR can enhance corporate transparency and create value in both mandatory and voluntary settings.

The paper is structured as follows: the following section discusses relevant literature and develops hypotheses. Section 3 introduces the methodology; the empirical results are discussed in Section 4. The conclusion is provided in Section 5.

\section{Relevant Literature and Hypothesis Development}

\subsection{Does the adoption of IR improve corporate transparency?}

Institutional theory provides an insight into mandatory and voluntary reporting systems. It suggests that an organization seeks to gain legitimacy through institutional and market pressures within its business environment. According to institutional theory, in order to survive, organizations must follow certain rules, norms, and belief systems (DiMaggio and Powell, 1983; Scott, 2014). Although there are many different interpretations of the theory, a large number of commentators consider how organizations behave under certain scenarios. DiMaggio and Powell (1983) describe three isomorphic processes, namely, regulative, mimetic, and normative. For 
instance, under uncertainty, many organizations will simply comply with regulations or laws (regulative process), others may copy other respected institutions (mimetic process), and the training and professional backgrounds of key personnel may also influence how organizations react (normative process). These isomorphic processes generate pressures to which individual organizations respond. Organizational adoption of regulations and/or best practices may vary due to competition, institutional environments, and the intensity of those environments. Responses to such factors shape organizations' decisions on whether to reveal (or withhold) risk information under these two reporting systems of voluntary and mandatory adoption of integrated reporting. While those decisions might be dominated by one particular pillar (pressure), the others are likely to work alongside it (e.g., Elshandidy et al., 2015).

It has been argued that the conventional reporting system under annual reports seemed to fail in capturing the economic changes for a business in a timely manner (e.g., Lee and Yeo, 2016). Some argued (FRC, 2011) that the less relevance of annual reports to shareholders is mainly due to the complex structure and length of these reports. In some contexts, such as South Africa, where the system is mandatorily adopting IR system, there is still room for firms to select the form, content, and details of their IR as firms apply IR on a principles basis to reflect the variations in each organization's circumstances (Lee and Yeo, 2016). They develop an index to capture the compliance with IR framework in South Africa during three years of 2010-2013 and find that firms that adopted IR have gained benefits ought that exceed its costs. Lee and Yeo's (2016) findings suggest that there were variations in disclosure practices in South Africa as firms have considerable discretion over IR disclosures.

By analysing one Italian company (Generali), Chiara et al. (2020) question whether the identification of material topics in IR is significantly different from sustainability reporting. Significant differences between these two different reporting systems are expected according to institutional theory, which suggests that each system is motivated by different incentives and logic since IR is mainly driven by market logic, whereas sustainability reporting is mainly driven by 
stakeholder desires and logic. The materiality of a specific topic is measured by looking at the volume of information firms provide, to meet investors' requirements. Chiara et al. (2020) observed significant differences in identifying material topics between these two reporting systems.

This discussion suggests that firms are likely to have institutional pressures that significantly motivate firms to have various levels of corporate (risk) reporting under the setting of mandatory adoption of IR compared to AR setting in South Africa. As no prior research has compared the level of transparency in risk reporting between the conventional system of annual report and integrated reporting, we build the following non-directional hypothesis:

H1: The observed level of transparency of risk reporting is likely to be significantly different in integrated reporting compared to annual report.

\subsection{Does the textual risk disclosed in IR create value to shareholders and investors?}

Previous studies have examined the relationship between risk disclosure and, for instance, country's level of corruption (Agyei-Mensah, 2017); potential economic costs of the COVID-19 pandemic (Fassas et al., 2021); role of media (Zaman et al., 2018); financial performance (Oino, 2019); corporate governance (Lepore et al., 2018; Agyei-Mensah, 2017a); ownership structure (Elmagrhi et al., 2016); board of directors' composition (Torchia and Calabrò, 2016); country's regulative pressures (Crawford and Williams, 2010); legitimacy tactics (Rudkin, et al., 2019).

In particular, the impact of disclosures provided in IR on firm value can be explained based on two competing views. The first view supports a positive association between the content of IR and firm value, as IR is likely to improve the quality of disclosed information and that would lead to better allocation of market resources. If the market incorporates disclosed information in stock prices promptly, that is likely to improve market liquidity and thus improve the market value of firms. The other view argues that information disclosed in IR has a detrimental effect on shareholders. Consistent with proprietary theory, if IR forces firms to reveal sensitive information to competitors (costly information), then such information is likely to be associated negatively with firm valuations. In other words, if IR enforces firms to adopt organizational processes that are 
costly and have little benefit for firms, then the information disclosed in IR is likely to be negatively associated with stock prices and that supports the idea that the mandatory adoption of IR has negative effects on firm values.

This paper examines the effect of textual risk disclosure on firms' market value in the IR (compared to AR) context. In theory, disclosure mitigates agency conflicts by diminishing information asymmetry, which in turn affects firms' market valuation (Rhodes, 2010). Similarly, corporate disclosure might moderate information asymmetry; therefore, the demand for a firm's shares might be increased, since the disclosure ought to affect the firm's value (Hassan et al., 2009). Equally, it has been suggested that increased disclosure could add value to firms by reducing their cost of capital, as this generates interest in firms' securities (Al-Akra and Ali, 2012).

The current empirical research suggests mixed findings. The positive impact of disclosure on firm value is documented by several studies (e.g., Rhodes, 2010; Al-Akra and Ali, 2012). However, some other research finds that disclosure might have a negative impact on firm value. For example, based on a meta-analysis study of risk disclosure, Khlif and Hussainey (2016) conclude that companies tend to avoid risk disclosure to reduce its adverse effect on a firm's value, as investors might have multi-interpretations of risk information that could have a negative effect on the firm's value. Recently, Haj-Salem et al. (2020) also find that corporate risk disclosure has a negative and significant effect on firm value. Campbell et al. (2014) reveal that risk disclosure negatively and significantly affects stock prices and abnormal return occurs around the $10-\mathrm{K}$ release date, suggesting that this kind of information reduces the value of firms. They argue that the observed impact is expected as long as the impact of risk factors is due to variations in markets' perceptions of firms' risk (rather than cash flows).

Despite these mixed results around the impact of risk disclosure on market values, based on IR objectives, we argue that adopting IR should enhance the level of TRD, compared to AR, in both mandatory and voluntary settings. IR enriches corporate transparency and provides comprehensive disclosure about corporate risks (CIMA, 2016). This risk information mostly can 


\section{Methodology}

\subsection{Sample selection and data collection}

This paper examines the effects of corporate transparency and market value in the AR and the IR from 2009 till 2014. We select all public listed firms (43) that issued IRs in 2011 in South Africa. For these firms, we collect all integrated reporting from 2011 to 2014 and their annual reports for 2009 and 2010. We exclude 4 firms that did not have a complete set of reports and 19 firms without a complete set of financial data over this 6-year period. The final sample size from South Africa consists of 215 firm-year observations, including 144 integrated reports and 71 annual reports that were manually collected.

Similarly, we have selected our sample for the UK based on the following. Within the UK context, the engagement in IR is entirely a voluntary decision. In 2013 (the year of introducing IR) the number of firms that adopted IR in the UK was very limited, and as a result, we have collected IRs for 2014-2016. Additionally, we have collected ARs for 2008-2010. Consequently, we hand collected 119 reports (62 ARs and 57 IRs) for UK firms.

Data for firm value, as well as firm characteristics and corporate governance control variables are collected as follows. Share price, firm size, profitability, liquidity, leverage, firm risk, and market to book are obtained from Datastream. Board size, board independence, CEO duality, audit committee size, audit committee independence, and auditor quality are manually collected. 


\subsection{V ariable measurement}

Textual risk disclosure is our first dependent variable of interest, and we used the Diction Version 7 software to count frequencies of words that indicate risk in the narrative sections of annual reports and integrated reports over the sample period. This paper adopts a risk-word list that has been developed by Elshandidy et al. (2013), Elshandidy et al. (2015); Elshandidy and Neri (2015) and Elshandidy and Shrives (2016). This word list includes against, catastrophe (catastrophic), challenge (challenges), chance (chances), decline (declined), decrease (decreased), differ*, diversify*, fail (failure), fluctuate*, gain (gains), increase (increased), less, loss*, low*, peak (peaked), probable*, risk*, shortage, significant*, threat, unable, uncertain (uncertainty; uncertainties), reverse (reversed), viable" and derivatives of the words marked with a $*$ sign. ${ }^{1}$ Textual risk disclosure is measured by the percentage of risk-related words (identified above) in the narrative sections of AR or IR relative to all words coded in these sections for each firm in each year of the sample period. In addition, the firm's market value is the second dependent variable, which is calculated as the average of firm's share price during the three months after the release of annual report and integrated reporting (Nekhili et al., 2016).

This paper also controls for firm-specific characteristics, as prior literature shows that firmspecific characteristics affect the company's decision about corporate information disclosure. First, large firms experience much pressure due to the existence of agency problems (Elshandidy et al., 2018) and might reduce agency costs by disclosing more voluntary information. Linsley and Shrives (2006) find that firm size has a positive impact on the risk disclosure, where firm size is measured by the natural logarithm of total assets. Second, in order to signal much information to

\footnotetext{
${ }^{1}$ Ibrahim and Hussainey (2019) provide a review of commonly used risk-wordlists in recent literature. It is notable that our adopted risk-wordlist was the basis on which Ibrahim and Hussainey (2019) provided their wordlist. As was suggested by one of the anonymous referees, we have compared our risk wordlist with those suggested by Ibrahim and Hussainy (2019). In doing so, we have calculated textual risk disclosure for all narrative sections of annual reports in the UK between 2008-2010. We find that risk disclosure scores for both lists are not statistically different and both are significantly associated, suggesting that both wordlists are measuring fundamentally the same phenomenon.
} 
the public, highly profitable firms are willing to disclose more information (Elshandidy et al., 2013). We measure profitability by the return on equity.

Third, we use the variable liquidity to control risk disclosure. Firms with a good ability to pay short-term obligations are more likely to have a higher level of information disclosure (Elshandidy et al., 2013) ). We measure liquidity as the ratio of current assets to current liabilities. Fourth, Elshandidy et al. (2013) demonstrate that leverage is positively related to risk disclosure; Leverage is measured by the ratio of total debt to common equity. The last control variable is firm risk, as measured by the beta value. Risky firms have more incentive to disclose more risk information to reflect their underlying risks (Elshandidy et al., 2013). Campbell et al. (2014) and Elshandidy and Shrives (2016) find a positive association between market to book value and firm market indicators. Therefore, in addition to the above variables, we control for market to book value expecting a positive coefficient in our tests for firm's market value. Market to book is measured as the book value of equity divided by the market value of equity.

We also control for a set of corporate governance variables that prior research shows to be related with TRD and market indicators (e.g., Elshandidy and Neri, 2015). These variables are as follows: board size, measured by the natural logarithm of the total number of directors on the board; board independence, measured by the percentage of independent directors on the board; duality, measured as a dummy variable set to 1 if the CEO is also chairman of the board of directors and 0 otherwise; audit committee size, measured by the natural logarithm of the number of directors on the audit committee; audit committee independence, measured by the proportion of independent directors on the audit committee; audit quality, measured as a dummy variable set to 1 if the firm is audited by one of the big four auditors and 0 otherwise. Following prior research on corporate governance and firm risk disclosure practises (e.g., DeFond and Francis, 2005; Li et al., 2012; Elshandidy et al. 2013; Elshandidy and Neri, 2015), we expect a positive (negative) association between board size, board independence, (duality), audit committee independence, and audit committee independence and the level of TRD. The evidence is mixed on the impact of 
audit committee size and firm disclosure practices as, while some findings support a positive association with disclosure practices (Li et al., 2012), some other studies report that larger audit committees are not associated with more disclosure in the case of their transition to IFRSs (Kent and Stewart, 2008). Finally, some prior literature on risk reporting (e.g., Elshandidy et al., 2013; Elshandidy and Neri, 2015) finds that audit quality affects firms' decisions to disclose information about their risks. Audit quality is measured as a dummy variable, which takes the value 1 if the external auditor of the company is one of the "big four" and 0 otherwise. Appendix 1 summarizes all variables definitions, measures, and sources.

\subsection{Empirical model}

To observe the relationships between integrated reporting adoption and the level of textual risk disclosure, we estimate the following ordinary least squares (OLS) regression models (testing H1):

$T R D_{i t}=\beta_{0}+\beta_{1} I R_{i t}+\sum_{j=1}^{n j} \beta_{j}$ Controls $_{j i t}+\varepsilon_{i t}$

$T R D_{i t}=\beta_{0}+\beta_{1} I R_{i t}+\beta_{2} S A_{i t}+\beta_{3} I R * S A_{i t}+\sum_{j=1}^{n j} \beta_{j}$ Controls $_{j i t}+\varepsilon_{i t}$,

Equation (1)

Equation (2)

where, in Equation (1), IR, our independent variable of interest, capturing the impact of integrated reporting, is a dummy variable that takes a value of 1 in an integrated reporting period and 0 otherwise (i.e., annual report period). In equation (2), SA is a dummy variable that takes a value of 1 in South Africa's mandatory integrating reporting system and 0 otherwise (i.e., in the UK voluntary integrating reporting system). $I R * S A$, our independent variable of interest, captures the impact of mandatory adoption of integrated reporting in South Africa (relative to the voluntary adoption in the UK). TRD refers to the textual risk disclosure and Controls refers to the set of firm characteristics and corporate governance control variables. All variables (as defined and measured in the previous section) in Equation (1) and (2) are measured for firm $i$ at time $t$, and $\varepsilon_{\mathrm{i}}$ is an error term. 


\section{Empirical Results}

\subsection{Descriptive statistics}

Table 1 gives the descriptive statistics for all firms regardless of which form of reports they provided over the sample period. Over the six-year period, firms' narratives contained on average $1.54 \%$ risk information or 982 risk-related words $(1.54 \% * 63756$, the average (unreported) of the length of reports over the period of study) based on the risk-word list adopted from Elshandidy and Neri (2015). The observed risk disclosure inter-quartiles ranging from 1.35 (or 861 risk-related words $=1.35 * 63756$ ) to 1.71 (or 1090 risk-related words=1.71*63756), imply a significant crosssectional variation in the content of the reports. Similarly, our sample firms show an average share price of 47.76. The variable's inter-quartiles ranging from 6.21 to 72.08 suggesting a significant cross-sectional variation in the firms' market value.

From the same table, we find that firms tended to have 11 directors $(2.71 * 2.37)$ on their boards. Around $56 \%$ of those directors were independent directors (those who had no business relations with the firms). Firms also tended to have audit committees with around four directors on their boards. Among those, 95\% (3 directors) are classified as independent members. Most 
firms (99\%), over the period of study, separated the roles of CEO and chairperson. $89 \%$ of reports under analysis, on average, were audited by one of the big four firms: Ernst \& Young, Deloitte \& Touche, KPMG, and PricewaterhouseCoopers. Additionally, the mean values of our sample's Firm size, Profitability, Liquidity, Leverage, and Firm risk are 13.751, 0.194, 1.881, 0.660, and 0.366 , respectively.

\section{[Insert Table 1 about here]}

Table 2 gives descriptive statistics for this paper's variables after making a distinction between the types of report, i.e., annual or integrated. While the proportion of risk information revealed in the AR was $1.62 \%$ (1047 risk-related-words or $1.62 \% * 64474)$, the proportion of risk information revealed on average in the IR over the period of study was $1.50 \%$ (956 risk-relatedwords or $1.50 \% * 63401)$. The difference between the average proportions of risk information revealed in these two outlets is statistically and negatively significant (t-statistic of -2.987with a significance level of $1 \%$ ), suggesting that there is a significant difference in the levels of textual risk disclosure after engaging in the mandatory practice of integrated reporting in South Africa. The trend of the mean differences suggests that the amount of risk information revealed in IR is significantly less than the information revealed in the ARs, as opposed to the same period in the UK where IR is voluntarily adopted (increasing reporting trend; t-statistic of 3.249 with a significance level of $1 \%$; full descriptive statistics are untabulated for brevity). This is also consistent with the decline in the length of IRs (63401 words) compared to the ARs (64474 words) over the period of study. Notably, the attention is on the level (the amount) of risk disclosure; the outcome might be different if the focus was on the content (the quality) of risk information by examining the depth of such information (Elshandidy et al., 2018). Collectively, these descriptive results suggest that the voluntary nature of IR in the UK and the conventional AR encourage managers to provide higher levels of risk information than they do in the mandatory IR context in South Africa. Panel B of the same table shows that almost $89 \%$ of the published reports (whether 
annual or integrated reports) are audited by one of the big auditing firms, implying that the previous differences are less likely to be contingent on the reporting quality.

\section{[Insert Table 2 about here]}

\subsection{Correlation analysis}

To understand how risk information and market value are related with firm characteristics and CG factors, Table 3 presents the bivariate correlations for all variables used in our analyses regardless of the outlet of information (whether annual or integrated reports). Table 3 shows that firms with a smaller board of directors, smaller audit committees, fewer independent directors on the board and on the audit committee, as well as audited by a non-big four audit firm, are likely to provide high levels of risk information. These results are consistent with prior research on risk disclosure (e.g., Elshandidy and Neri, 2015). Regarding firm characteristics, we find that smaller firms have incentives to provide higher levels of risk information in their narrative sections compared to larger firms. Further, firms with low profitability and high volatile market value are likely to provide more information about their risks. Those firms will be under the market spotlight, and therefore their managers might be under pressure if they release less information. This result is also consistent with prior research on risk disclosure (e.g., Elshandidy et al., 2013). Additionally, we find that firm market value is mostly correlated in the expected direction with the study's variables (e.g., Elshandidy and Neri, 2015).

\section{[Insert Table 3 about here]}

Table 4 further gives the association between risk disclosure, firm value, firm characteristics, and governance factors in ARs (below the diagonal) and IRs (above the diagonal). With regard to IR, TRD has a significantly positive (negative) association with Liquidity and Firm risk (Firm size, Profitability, Leverage, Board size, Board independence, and Audit committee size). In addition, Price has a significantly positive (negative) association with Firm size, Profitability, Leverage, Market to book, Board independence, and Audit committee size (Liquidity, Firm risk, and Audit committee size). For AR, TRD shows a significantly positive (negative) association with 
Liquidity and Firm risk (Firm size, Profitability, Board independence, Audit committee size, Audit committee independence, Audit quality). Price shows a significantly positive (negative) association with Firm size, Board independence, Audit committee size, and Audit committee independence (Firm risk). Collectively, variables correlated with risk disclosure and firm value in the ARs and IRs are quite consistent. In order to assess the extent to which these relations are associate with IR mandatory setting (relative to the voluntary IR setting and the conventional AR setting), we turn to multivariate analyses. ${ }^{2}$

\subsection{OLS Regression}

\section{[Insert Table 4 about here]}

\subsubsection{Integrated reporting and the level of TRD (H1)}

This section discusses our paper's first hypothesis on the impact of adopting IR on the level of TRD. In doing so, Models 1, 2, 3 of Tables 5 provide the OLS coefficient estimates for Equation (1) in terms of the South Africa in setting (SA, where IR adoption is mandatory), the UK (where IR adoption is voluntary), as well as both countries together. In these models, IR is our main variable of interest which we employ to capture the impact of integrated reporting adoption on the level of TRD. In Model 1, IR captures the impact of the mandatory IR adoption in SA on the level of TRD (our measure of transparency).

In the meantime, we employ IR in Models 2 and 3 to investigate the behavior of TRD during the same period in an IR voluntarily adoption setting (UK) and in both countries together. This enables us to ensure that the IR results in Model 1 are uniquely driven by the mandatory context in SA. Furthermore, in Model 4 of Table 5, consistent with Equation (2), we employ the difference-in-difference method in which the interaction term of IR*SA is our main variable of interest. In this powerful design, $\mathrm{IR} * \mathrm{SA}$ enables us to capture the relative difference in relation to the mandatory adoption of IR. Put differently, IR*SA indicates the impact of the mandatory

\footnotetext{
${ }^{2}$ Throughout our tests, we assess the effects of multicollinearity by calculating the variance inflation factors (VIFs) for each independent variable entered in the multivariate regressions. With VIFs less than 10, we conclude that multicollinearity is not a concern.
} 
adoption of integrated reporting in SA relative to adopting a voluntary model of reporting or the voluntary adoption of IR in the UK.

\section{[Insert Table 5 about here]}

The time-series difference Models 1, 2, and 3 of Table 5 (Equation 1) display the coefficient estimates of the SA, UK, and both countries before and after the adoption of IR. Model 1, giving the results in the SA mandatory IR adoption regime, shows a statistically significant and negative coefficient on IR (t-statistic of -2.303 with a significance level of $5 \%$ ). On the other hand, Model 2, giving the results in the UK voluntary IR adoption regime, shows a statistically significant but positive coefficient on IR (t-statistic of 1.790 with a significance level of $10 \%)$. When we combine both countries, Model 3 shows a statistically insignificant coefficient on IR. We obtain confirmatory finding from the difference-in-differences Model 4, where IR*SA absorbs the net effect of IR mandatory adoption on TRD. Specifically, Model 4 shows a strong statistically significant and negative coefficient on IR*SA (t-statistic of -3.316 with a significance level of $1 \%$ ).

Collectively, these findings are consistent with our previous descriptive results and suggest that managers' adherence to the mandatory provision of integrated reporting drives them to decrease the level of TRD they used to convey within the conventional annual reports or they would voluntarily produce within a voluntary IR setting. This leads us to accept the first hypothesis, that the observed level of transparency of risk reporting is likely to be significantly different in IR compared to AR.

\subsubsection{The effect of risk disclosure on firm market value under IR setting (H2)}

In this section, we discuss our paper's second hypothesis on the impact of risk information conveyed during the adoption of IR, in both mandatory and voluntary settings, on the firm's market value. In a similar practice to that followed in the previous section, Models 1, 2, and 3 of Table 6 gives the OLS coefficient estimates for Equation (3) in terms of SA (where IR adoption is mandatory), UK (where IR adoption is voluntary), as well as both countries together. In these 
models, IR*TRD is our main variable of interest, which we employ to capture the impact of TRD on firm value in the post- relative to pre-adoption of IR.

In the context of mandatory and voluntary settings, Hassan et al. (2009) find that while voluntary disclosure has a positive association with firm value, mandatory disclosure has a significant and negative effect on firm value, suggesting the complexity of factors that determine the disclosure effects. Simillarly, Wahi et al. (2020) argue that factors that influence value creation of reporting in a mandatory setting are different from those that drive the effect in a voluntary setting, where potential improvements are expected, if the level of transparency and quality of reporting are not high, to observe improvements over what already exists and that, as a consequence, limits addition to current created value. Wahi et al. (2020) do not find evidence of improvement in value creation after voluntary adoption the IR. Inconsistently, we did not find a significant impact of the corporate reporting setting (either mandatory or voluntary) on corporate transparency and its firm value.

Interestingly, Models 1, 2, and 3 of Table 6 display trivial coefficients on IR*TRD, implying that the impact of TRD on firm value in the period of IR relative to the impact before the IR adoption is statistically not different from zero. Considering the lower level of TRD conveyed by managers after adopting IR (as indicated by previous results), it seems that investors do not consider TRD as an important factor in evaluating the firm's value. This leads us to reject the second hypothesis, that TRD is likely to negatively impact the firm's market value under the IR compared to AR context in both mandatory and voluntary settings

\section{[Insert Table 6 about here]}

\subsection{Further and robustness analysis}

IR supports managers in adopting a comprehensive control mechanism by implementing effective corporate governance (CG) mechanisms and achieving sufficient corporate transparency. Arguably, CG mechanisms should effectively manage the connectivity between IR framework concepts (e.g., risk and opportunities) to enhance corporate risk disclosure. Those charged with 
governance must exercise judgment in "distinguishing between information that is material and should therefore be included in the Integrated Report, and other information that may be relatively static or only relevant to some report users" (IIRC, 2011, p.13).

This motivates us to investigate whether the strength of a firm's CG environment moderates the relationship between IR adoption and the level of TRD. Following DeFond and Francis (2005), we employ our study's six control variables to construct an indicator of the strength of a firm's environment, CG_strength. Specifically, CG_strength is a dummy variable that takes the value of 1 if the firm's corporate governance summary is greater than the sample median and 0 otherwise. In this respect, we construct a CG summary measure that is equal to the sum of the study's six corporate governance variables. Each governance continuous variable is turned into a dichotomous variable that takes the value of 1 if it is greater than the sample median and 0 otherwise. Models 1, 2, and 3 of Table 7 unexpectedly show, however, insignificant coefficients on IR*CG_strength. This finding does not accord with IIRC and suggest that the strength of a firm's CG environment does not moderate the relationship between IR and TRD. This casts doubt on the role of CG in achieving sufficient corporate transparency under IR, as proposed by IIRC. Our findings are in line with that of Lee and Yeo (2016) in South Africa suggesting that the variations in disclosure practices under the IR regime are mainly driven by management discretion. This discretion, as to our results, drives managers to adhere to the mandatory provision of integrated reporting so as to decrease the level of TRD compared with what they used to convey within the conventional annual reports.

\section{[Insert Table 7 about here]}

In order to validate the insignificant finding in terms of the impact of TRD on firm value, Table 8 gives cross-sectional OLS results considering different reporting contexts. Specifically, we show the model estimations during the period before and after the adoption of IR in SA and the corresponding periods in UK, as well as for both countries combined. Although Model 1 shows a 
statistically significant and positive impact of TRD on firm value for both countries during the allsample period, Models 2-5 for the SA and UK still remain showing insignificant results in both periods before and after IR adoption. ${ }^{3}$

\section{[Insert Table 8 about here]}

\section{Conclusion}

This paper observes differences in transparency level (proxied by TRD) following the mandatory change in South Africa from the conventional reporting system of annual reports to another recent reporting system of integrated reporting. Our paper examines whether such transparency (textual risk) level improves or creates value relevance for stakeholders or not, and observes the impact of such disclosure on a firm's market value. These effects are examined in the both mandatory context of South Africa, and the voluntary context of the UK.

Our results, for the mandatory adoption of integrated reporting in South Africa, show that the level of risk information has significantly declined in integrated reporting as compared to the level of such disclosure that firms tended to reveal in annual reports. In examining the value relevance of risk information to shareholders, our results show that level of risk information does not statistically influence firms' value. In the context of UK, in contrast to South Africa, we find that the level of risk information has significantly increased following the voluntary adoption of the integrated reporting system compared to the level of disclosure UK firms use to provide under the reporting system of annual reports. The observable effect of this disclosure under both reporting systems is not statistically influential.

Our findings have several implications for stakeholders and policy-makers. The paper's findings should drive policy-makers (e.g., IIRC) to provide a clear and consensus definition of the

\footnotetext{
${ }^{3}$ Furthermore, we repeat all market value analyses (Equation 3) utilizing different indicators for firm market value in $t+1$; namely: market to book value (market value of equity over total equity) and Tobin's Q ((short-term debt + longterm debt + market value of equity)/total asset). Collectively, our unreported results remain qualitatively similar to that obtained previously.
} 
IR elements and principles ((Landau et al., 2020) by setting substantive guidance on adopting IR and they might also restructure the framework to achieve the desired objectives of IR and improve its quality. In addition, the current research has practical implications for investors to understand whether IR enhances corporate transparency and create value, or is just a fashionable corporate reporting practise that does not show significant informative differences than conventional AR. The paper also offers useful insights to corporate managers and practitioners to assess the worth of adopting IR by assessing the costs and benefits of such adoption. Practically, our findings extend the debate about the practical usefulness of the content of adopted IR. Based on the principles and components of the IR framework, companies should enhance transparency through emphasizing information disclosure. UK companies follow the IR guidelines and reveal more risk information than they used to release within the AR context, however, this does significantly impact the firm's market value. This conclusion might explain why the IR “movement has lost some of its momentum and is increasingly the subject of heated debate and controversy" (Oll and Rommerskirchen, 2018, p. 19). KPMG (2017) reported that, in 2017, 14\% of G250 reporting companies produced an integrated report, versus 15\% in 2015.

Cross-country research is required to compare disclosure practices in integrated reporting and look at country and firm factors that might affect those practices. Further research is also required to investigate the quality rather than the quantity of disclosure practices. It might be useful while developing such a measure to rely on the integrated reporting framework. Comparison of the readability level between the AR and IR is another area that might be usefully investigated in order to determine the incentives and the economic consequences. Recently, in 2014, the UK has provided a strategic report. However, very little is known about this new reporting system and its relation to the integrated reporting system, making this another practical avenue for future investigation. 


\section{References}

Abraham, S. and Shrives, P.J. (2014), "Improving the relevance of risk factor disclosure in corporate annual reports", The British Accounting Review, Vol. 46 No. 1, pp. 91-107.

Adams, C. A. (2015). The International Integrated Reporting Council: A call to action. Critical Perspectives on Accounting, Vol. 27, pp. 23-28.

Adams, C. A., Potter, B., Singh, P. J. and York, J. (2016), "Exploring the implications of integrated reporting for social investment (disclosures)", The British Accounting Review, Vol. 48 No. 3, pp. 283-296.

Agyei-Mensah, B.K., (2017), "Does the corruption perception level of a country affect listed firms' IFRS 7 risk disclosure compliance?", Corporate Governance: The International Journal of Business in Society, Vol. 17 No. 4, pp. 727-747.

Agyei-Mensah, B.K., (2017a), "The relationship between corporate governance mechanisms and IFRS 7 compliance: Evidence from an emerging market", Corporate Governance: The International Journal of Business in Society. Vol. 17 No. 3, pp. 446-465.

Al-Akra, M. and Ali, M. J. (2012), "The value relevance of corporate voluntary disclosure in the Middle-East: The case of Jordan", Journal of Accounting and Public Policy, Vol. 31 No. 5, pp. 533549.

Albitar, K., Hussainey, K., Kolade, N. and Gerged, A. M. (2020), "ESG disclosure and firm performance before and after IR", International Journal of Accounting \& Information Management, Vol. 28 No. 3, pp.429-444.

Barth, M., Cahan, S., Chen, L. and Venter, E. R. (2017), "The economic consequences associate with integrated reporting quality: Capital market and real effects", Accounting, Organizations and Society, Vol. 62, pp. 43-64.

Brown, J. and Dillard, J. (2014), "Integrated reporting: On the need for broadening out and opening up", Accounting, Auditing \& Accountability Journal, Vol. 27 No.7, pp. 1120-1156.

Busco, C., Frigo, M. L., Quattrone, P., and Riccaboni, A. (2013), "Redefining corporate accountability through integrated reporting", Strategic Finance, Vol. 8, pp. 33-41.

Campbell, J. L., Chen, H., Dhaliwal, D. S., Lu, H. and Steele, L. B. (2014), "The information content of mandatory risk factor disclosure in corporate filings". Review of Accounting Studies, Vol. 19 No. 1, pp. 396-455.

Carcello, J. V. and Li, C. (2013), "Costs and benefits of requiring an engagement partner signature: Recent experience in the United Kingdom", The Accounting Review, Vol. 88 No. 5, pp. 1511 1546.

CIMA (Chartered Institute of Management Accountants). (2016), "Integrated reporting in the public sector", available at: http://integratedreporting.org/resource/cima-integratedreporting-in-the-public-sector/ (accessed 10 March 2021).

Cormier, D. and Magnan, M., (2014), "The impact of social responsibility disclosure and governance on financial analysts' information environment", Corporate Governance: The International Journal of Business in Society, Vol. 14 No. 4, pp. 467-484.

Crawford, E.P. and Williams, C.C., (2010), "Should corporate social reporting be voluntary or mandatory? Evidence from the banking sector in France and the United States", Corporate Governance: The International Journal of Business in Society, Vol. 10 No. 4, pp. 512-526.

De Villiers, C., Rinaldi, L. and Unerman, J. (2014), "Integrated reporting: Insights, gaps and an agenda for future research", Accounting, Auditing \& Accountability Journal, Vol. 27 No. 7, pp. 1042-1067.

DeFond, M. L. and Francis, J. R. (2005), "Audit research after South Africa Sarbanes-Oxley", Auditing: A Journal of Practice \& Theory, Vol. 24, pp.5-30.

DiMaggio, P. J. and Powell, W. W. (1983), "The iron cage revisited: Institutional isomorphism and collective rationality in organizational fields", American Sociological Review, pp. 147-160. 
Doyle, J. T. and Magilke, M. J. (2013), "Decision usefulness and accelerated filing deadlines", Journal of Accounting Research, Vol. 51 No. 3, pp. 549-581.

Dumay, J., Bernardi, C., Guthrie, J. and La Torre, M. (2017), "Barriers to implementing the international integrated reporting framework", Meditari Accountancy Research, Vol. 25 No. 4, pp. 461-480.

Dyer, T., Lang, M. and Stice-Lawrence, L. (2017), "The evolution of 10-K textual disclosure: Evidence from Latent Dirichlet Allocation" Journal of Accounting and Economics, Vol. 64 No. 23, pp. 221-245.

El-Diftar, D., Jones, E., Ragheb, M. and Soliman, M., (2017), "Institutional investors and voluntary disclosure and transparency: the case of Egypt", Corporate Governance: The International Journal of Business in Society, Vol. 17 No. 1, pp. 134-151.

Elmagrhi, M.H., Ntim, C.G. and Wang, Y., (2016), "Antecedents of voluntary corporate governance disclosure: A post-2007/08 financial crisis evidence from the influential UK Combined Code", Corporate Governance: The International Journal of Business in Society, Vol. 16 No. 3, pp. 507-538.

Elshandidy, T. and Neri, L. (2015), "Corporate Governance, Risk Disclosure Practices, and Market Liquidity: Comparative Evidence from the UK and Italy", Corporate Governance: An International Review, Vol. 23 No 4, pp. 331-356.

Elshandidy, T. and Shrives, P. J. (2016), "Environmental incentives for and usefulness of textual risk reporting: Evidence from Germany." The International Journal of Accounting, Vol. 51 No. 4, pp. 464-486.

Elshandidy, T., Fraser, I. and Hussainey, K. (2013), “Aggregated, voluntary, and mandatory risk disclosure incentives: Evidence from UK FTSE all-share companies" International Review of Financial Analysis, Vol. 30, pp. 320-333.

Elshandidy, T., Fraser, I. and Hussainey, K. (2015), "What drives mandatory and voluntary risk reporting variations across Germany, UK and US?", The British Accounting Review, Vol. 47 No 4, pp. 376-394.

Elshandidy, T., Neri, L. and Guo, Y. (2018), "Determinants and impacts of risk disclosure quality: evidence from China", Journal of Applied Accounting Research, Vol 19 No 4, pp. 518-536.

Fassas, A., Bellos, S. and Kladakis, G., (2021), "Corporate liquidity, supply chain and cost issues awareness within the Covid-19 context: evidence from us management reports' textual analysis", Corporate Governance: The International Journal of Business in Society, DOI 10.1108/CG09-2020-0399.

Guthrie, J., Rossi, F. M., Orelli, R. L. and Nicolò, G. (2020), "Investigating risk disclosures in Italian integrated reports", Meditari Accountancy Research, Vol. 28 No. 6, pp. 1149-1178.

Haj-Salem, I., Ayadi, S. D. and Hussainey, K. (2020), "The joint effect of corporate risk disclosure and corporate governance on firm value", International Journal of Disclosure and Governance, Vol. 17 No. 2, pp.123-140.

Hassan, O. A., Romilly, P., Giorgioni, G. and Power, D. (2009), "The value relevance of disclosure: Evidence from the emerging capital market of Egypt", The International Journal of Accounting, Vol. 44 No. 1, pp.79-102.

Hosoda, M., (2021), "Integrated reporting and changes in management control systems in large Japanese companies", Corporate Governance: The International Journal of Business in Society, Vol. 21 No. 3, pp. 397-409.

Ibrahim, A. E. A. and Hussainey, K. (2019), "Developing the narrative risk disclosure measurement" International Review of Financial Analysis, Vol. 64, pp. 126-144.

IIRC (2011). "Towards Integrated Reporting: Communicating Value in the $21^{\text {st }}$ Century", the International Integrated Reporting Committee, available at: https://integratedreporting.org/wp-content/uploads/2011/09/IR-Discussion-Paper2011 spreads.pdf (accessed 12th July 2021). 
IIRC (2013). "The International Integrated Report Framework", the International Integrated Reporting Committee, available at: https://integratedreporting.org/wpcontent/uploads/2015/03/13-12-08-THE-INTERNATIONAL-IR-FRAMEWORK-21.pdf (accessed 12th July 2021).

IRCSA. (2011), "Discussion Paper: Framework for Integrated Reporting and the Integrated Report. South Africa", the Integrated Reporting Committee of South Africa, Cape Town South Africa.

Kent, P. and Stewart, J. (2008), "Corporate governance and the disclosure by Australian companies of the impact of international financial reporting standards", Accounting and Finance, Vol. 48, pp. 649-671.

Khlif, H. and Hussainey, K. (2016), "The association between risk disclosure and firm characteristics: a meta-analysis", Journal of Risk Research, Vol. 19 No. 2, pp. 181-211.

Kothari, S. P., Li, X. and Short, J. E. (2009). The effect of disclosures by management, analysts, and business press on cost of capital, return volatility, and analyst forecasts: A study using content analysis. The Accounting Review, Vol. 84 No. 5, pp. 1639-1670.

KPMG (2017), “The road ahead. The KPMG survey of corporate responsibility reporting 2017”, available at: https://integratedreporting.org/wp-content/uploads/2017/10/kpmg-survey-ofcorporate-responsibility-reporting-2017.pdf, (accessed 10 December 2020).

Kravet, T. and Muslu, V. (2013), "Textual risk disclosures and investors' risk perceptions." Review of Accounting Studies, Vol. 18 No. 4, pp. 1088-1122.

Landau, A., Rochell, J., Klein, C. and Zwergel, B. (2020), "Integrated reporting of environmental, social, and governance and financial data: Does the market value integrated reports?" Business Strategy and the Environment, Vol. 29 No. 4, pp. 1750-1763.

Lee, K. W. and Yeo, G. H. H. (2016), "The association between integrated reporting and firm valuation", Review of Quantitative Finance and Accounting, Vol 47 No. 4, pp. 1221-1250

Lepore, L., Pisano, S., Di Vaio, A. and Alvino, F., (2018), "The myth of the "good governance code": an analysis of the relationship between ownership structure and the comply-or-explain disclosure", Corporate Governance: The International Journal of Business in Society, Vol. 18 No. 5, pp. 809-838.

Leuz, C. and Wysocki, P. D. (2016), "The economics of disclosure and financial reporting regulation: Evidence and suggestions for future research", Journal of Accounting Research, Vol. 54 No. 2, pp. 525-622.

Linsley, P. M. and Shrives, P. J. (2005), "Transparency and the disclosure of risk information in the banking sector" Journal of Financial regulation and Compliance, Vol 13 No 3, pp. 205-214.

Linsley, P. M. and Shrives, P. J. (2006), "Risk reporting: A study of risk disclosures in the annual reports of UK companies", The British Accounting Review, Vol. 38, No. 4, pp. 387-404.

Masegare, P. and Ngoepe, M., (2018), "A framework for incorporating implementation indicators of corporate governance for municipalities in South Africa", Corporate Governance: The International Journal of Business in Society, Vol. 18 No. 4, pp. 581-593.

McNally, M. A., Cerbone, D. and Maroun, W. (2017), "Exploring the challenges of preparing an integrated report", Meditari Accountancy Research. Vol. 25 No. 4, pp. 481-504

Mervelskemper, L. and Streit, D. (2017), "Enhancing market valuation of ESG performance: Is integrated reporting keeping its promise?", Business Strategy and the Environment, Vol. 26 No. 4, pp. 536-549.

Moolman, J., Oberholzer, M. and Steyn, M. (2016), "The effect of integrated reporting on integrated thinking between risk, opportunity and strategy and the disclosure of risks and opportunities", Southern African Business Review, Vol. 20 No. 1, pp. 600-627.

Morgan, G., Ryu, K. and Mirvis, P., (2009), "Leading corporate citizenship: governance, structure, systems", Corporate Governance: The International Journal of Business in Society, Vol. 9 No. 1, pp. 3949. 
Naheed, R., AlHares, A., Shahab, Y. and Naheed, R., (2021), "Board's financial expertise and corporate social responsibility disclosure in China", Corporate Governance: The International Journal of Business in Society, Vol. 21 No. 4, pp. 716-736.

Nekhili, M., Hussainey, K., Cheffi, W., Chtioui, T. and Tchakoute-Tchuigoua, H. (2016), "R\&D narrative disclosure, corporate governance and market value: Evidence from France", Journal of Applied Business Research, Vol. 32 No. 1, pp. 111-128.

Oino, I., (2019), "Do disclosure and transparency affect bank's financial performance?”, Corporate Governance: The International Journal of Business in Society, Vol. 19 No. 6, pp. 1344-1361.

Oliver, C. (1991), "Strategic responses to institutional processes", Academy of Management Review, Vol. 16 No. 1, pp. 145-179.

Oll, J. and Rommerskirchen, S. (2018), "What's wrong with integrated reporting? A systematic review", In Nachhaltigkeits Management Forum| Sustainability Management Forum, Vol. 26 No. 1-4, pp. 19-34.

Raemaekers, K., Maroun, W. and Padia, N. (2016), "Risk disclosures by South African listed companies post-King III", South African Journal of Accounting Research, Vol. 30 No. 1, pp. 41-60.

Rhodes, M. J. (2010), "Information asymmetry and socially responsible investment", Journal of Business Ethics, Vol. 95 No. 1, pp. 145-150.

Rudkin, B., Kimani, D., Ullah, S., Ahmed, R. and Farooq, S.U., (2019), "Hide-and-seek in corporate disclosure: evidence from negative corporate incidents", Corporate Governance: The International Journal of Business in Society, Vol. 19 No. 1, pp. 158-175.

Torchia, M. and Calabro, A., (2016), "Board of directors and financial transparency and disclosure. Evidence from Italy", Corporate Governance: The International Journal of Business in Society, Vol. 16 No. 3, pp. 593-608.

Scott, W. R. (2014), Institutions and Organizations, (4th ed.), Thousand Oaks, CA: Sage Publications

Serafeim, G. (2015), "Integrated reporting and investor clientele", The Journal of Applied Corporate Finance, Vol. 27 No. 2, pp. 34-51.

Vitolla, F., Raimo, N., Rubino, M. and Garzoni, A. (2019), "How pressure from stakeholders affects integrated reporting quality", Corporate Social Responsibility and Environmental Management, Vol. 26 No. 6, pp. 1591-1606.

Wahl, A., Charifzadeh, M. and Diefenbach, F. (2020), "Voluntary Adopters of Integrated Reporting-Evidence on Forecast Accuracy and Firm Value", Business Strategy and the Environment, Vol. 29 No. 6, pp.2542-2556.

Zaman, R., Bahadar, S., Kayani, U.N. and Arslan, M., (2018), "Role of media and independent directors in corporate transparency and disclosure: evidence from an emerging economy", Corporate Governance: The International Journal of Business in Society, Vol. 18 No. 5, pp. 858-885. 
Table 1. Descriptive statistics for all reports

\begin{tabular}{|c|c|c|c|c|c|c|}
\hline & $\mathrm{N}$ & Mean & Median & Std.Dev. & Q1 & Q3 \\
\hline $\operatorname{TRD}(\%)$ & 215 & 1.544 & 1.551 & 0.280 & 1.353 & 1.710 \\
\hline Price & 190 & 47.755 & 31.018 & 52.184 & 6.207 & 72.083 \\
\hline Firm size & 215 & 13.751 & 13.855 & 1.344 & 12.732 & 14.722 \\
\hline Profitability & 215 & 0.194 & 0.184 & 0.250 & 0.082 & 0.310 \\
\hline Liquidity & 215 & 1.881 & 1.470 & 1.250 & 1.060 & 2.360 \\
\hline Leverage & 215 & 0.660 & 0.237 & 1.373 & 0.120 & 0.509 \\
\hline Firm risk & 215 & 0.366 & 0.314 & 0.186 & 0.242 & 0.430 \\
\hline Market to book & 191 & 3.250 & 2.020 & 2.963 & 1.150 & 4.380 \\
\hline Board size & 215 & 2.367 & 2.398 & 0.234 & 2.197 & 2.565 \\
\hline Board independence & 215 & 0.560 & 0.563 & 0.140 & 0.444 & 0.667 \\
\hline Duality & 215 & 0.009 & 0.000 & 0.096 & 0.000 & 0.000 \\
\hline Audit committee size & 215 & 1.265 & 1.099 & 0.225 & 1.099 & 1.386 \\
\hline Audit committee independence & 215 & 0.949 & 1.000 & 0.132 & 1.000 & 1.000 \\
\hline Audit quality & 215 & 0.888 & 1.000 & 0.316 & 1.000 & 1.000 \\
\hline
\end{tabular}

Notes: This table presents the descriptive statistics of textual risk disclosure, firm value measured by firm's share price, and a set of control variables including firm characteristics and corporate governance variables for all reports. TRD is measured by the \% of words indicating risk based on risk-word list. Price measures firm value and is calculated as the average of firm's share price during the three months after the release of annual report and integrated reporting. Firm characteristics are as follows: Firm size is captured by the log of total assets. Profitability is captured by the return on equity. Liquidity is captured by the current ratio. Leverage is measured by the ratio of total debt to common equity. Firm risk is captured by volatility. Market to book measures market value of equity/total equity. All continuous variables are winsorized at $1 \%$ on both tails. Corporate governance includes the following variables: Board size is measured by the log of the total number of directors on the board. Board independence is measured by the percentage of independent directors on the board. Duality is measured as a dummy variable, which takes the value 1 if the role of CEO and the chairman of the board is the same person and 0 otherwise. Audit committee size is measured by the log of the number of directors of the audit committee. Audit committee independence is measured by proportion of independent directors of the audit committee. Audit quality is a dummy variable, which takes the value 1 if the external auditor of the company is one of the "big four" and 0 otherwise. 
Table 2. Descriptive statistics for annual and integrated reports and differences

\begin{tabular}{|c|c|c|c|c|c|c|c|c|c|c|c|c|}
\hline & \multicolumn{5}{|c|}{ Annual report (AR) } & \multicolumn{5}{|c|}{ Integrated reporting (IR) } & \multicolumn{2}{|c|}{ Difference t-statistics } \\
\hline & $\mathrm{N}$ & Mean & Std.Dev. & Q1 & Q3 & $\mathrm{N}$ & Mean & Std.Dev. & Q1 & Q3 & SA & $\mathrm{UK}$ \\
\hline $\operatorname{TRD}(\%)$ & 71 & 1.624 & 0.258 & 1.461 & 1.779 & 144 & 1.505 & 0.283 & 1.323 & 1.683 & $-2.987 * * *$ & $3.249 * * *$ \\
\hline Price & 69 & 39.755 & 40.369 & 7.156 & 63.488 & 121 & 52.317 & 57.513 & 6.207 & 76.584 & 1.602 & $1.745^{*}$ \\
\hline Firm size & 71 & 13.558 & 1.336 & 12.468 & 14.415 & 144 & 13.846 & 1.342 & 13.069 & 14.779 & & \\
\hline Profitability & 71 & 0.212 & 0.303 & 0.097 & 0.365 & 144 & 0.184 & 0.219 & 0.071 & 0.295 & & \\
\hline Liquidity & 71 & 1.882 & 1.219 & 1.060 & 2.280 & 144 & 1.880 & 1.269 & 1.070 & 2.380 & & \\
\hline Leverage & 71 & 0.897 & 1.781 & 0.106 & 0.596 & 144 & 0.542 & 1.109 & 0.121 & 0.481 & & \\
\hline Market to book & 69 & 3.107 & 2.879 & 1.180 & 3.960 & 122 & 3.331 & 3.018 & 1.150 & 4.830 & & \\
\hline Board size & 71 & 2.372 & 0.248 & 2.197 & 2.565 & 144 & 2.364 & 0.228 & 2.197 & 2.565 & & \\
\hline Board independence & 71 & 0.539 & 0.133 & 0.429 & 0.643 & 144 & 0.570 & 0.143 & 0.449 & 0.667 & & \\
\hline Duality & 71 & 0.014 & 0.119 & 0.000 & 0.000 & 144 & 0.007 & 0.083 & 0.000 & 0.000 & & \\
\hline Audit committee size & 71 & 1.261 & 0.232 & 1.099 & 1.386 & 144 & 1.267 & 0.222 & 1.099 & 1.386 & & \\
\hline Audit committee independence & 71 & 0.917 & 0.152 & 0.800 & 1.000 & 144 & 0.964 & 0.119 & 1.000 & 1.000 & & \\
\hline Audit quality & 71 & 0.887 & 0.318 & 1.000 & 1.000 & 144 & 0.889 & 0.315 & 1.000 & 1.000 & & \\
\hline
\end{tabular}

Notes: This table presents the descriptive statistics of textual risk disclosure, firm value, as well as firm characteristics and corporate governance control variables for the annual reports and integrated reports. The difference of disclosure and firm value variables between annual report and integrated reporting is identified. SA and UK denote the differences in terms of South Africa and UK (unreported for brevity). The difference t-statistics are shown in the last column. *, ** and $* * *$ indicate two-tailed significance at $10 \%, 5 \%$ and $1 \%$ respectively. All continuous variables are winsorized at $1 \%$ on both tails. All variables definitions, measures and sources are provided in Appendix 1.. 
Table 3. Correlation analysis for all

\begin{tabular}{|c|c|c|c|c|c|c|c|c|c|c|c|c|c|c|}
\hline & (1) & (2) & (3) & (4) & (5) & (6) & (7) & (8) & (9) & (10) & (11) & (12) & (13) & (14) \\
\hline (1) $T R D$ & 1.000 & & & & & & & & & & & & & \\
\hline (2) Price & $-0.525^{*}$ & 1.000 & & & & & & & & & & & & \\
\hline (3) Firm size & $-0.600^{*}$ & $0.578^{*}$ & 1.000 & & & & & & & & & & & \\
\hline (4) Profitability & $-0.140^{*}$ & $0.177 *$ & 0.004 & 1.000 & & & & & & & & & & \\
\hline (5) Liquidity & $0.230^{*}$ & $-0.186^{*}$ & $-0.246^{*}$ & -0.098 & 1.000 & & & & & & & & & \\
\hline (6) Leverage & $-0.165^{*}$ & $0.132^{*}$ & $0.141 *$ & $0.120^{*}$ & $-0.287^{*}$ & 1.000 & & & & & & & & \\
\hline (7) Firm risk & $0.356^{*}$ & $-0.255^{*}$ & $-0.47 *$ & $-0.395^{*}$ & $0.116^{*}$ & -0.061 & 1.000 & & & & & & & \\
\hline (8) Market to book & $-0.142^{*}$ & $0.247^{*}$ & 0.015 & $0.579 *$ & $-0.208^{*}$ & $0.364^{*}$ & $-0.367^{*}$ & 1.000 & & & & & & \\
\hline (8) Board size & $-0.152 *$ & 0.080 & $0.443^{*}$ & -0.106 & 0.011 & -0.034 & $-0.227^{*}$ & -0.071 & 1.000 & & & & & \\
\hline (9) Board independence & $-0.265^{*}$ & $0.381 *$ & $0.470^{*}$ & -0.009 & $-0.119 *$ & 0.075 & $-0.282^{*}$ & $0.188^{*}$ & 0.035 & 1.000 & & & & \\
\hline 10) Duality & -0.075 & -0.038 & 0.004 & -0.029 & -0.049 & 0.009 & -0.029 & 0.000 & 0.010 & -0.101 & 1.000 & & & \\
\hline $\begin{array}{l}\text { (12) Audit committee size } \\
\text { (13) Audit committee }\end{array}$ & $-0.330 *$ & $0.213^{*}$ & $0.349^{*}$ & -0.094 & -0.017 & 0.102 & $-0.123^{*}$ & 0.056 & $0.275^{*}$ & $0.296^{*}$ & 0.036 & 1.000 & & \\
\hline independence & $-0.199 *$ & $0.170^{*}$ & $0.313^{*}$ & 0.096 & $-0.111^{*}$ & -0.005 & $-0.343^{*}$ & $0.140^{*}$ & $0.207^{*}$ & $0.341^{*}$ & 0.034 & $-0.152^{*}$ & 1.000 & \\
\hline (14) Audit quality & $-0.137^{*}$ & $0.150^{*}$ & $0.306^{*}$ & 0.091 & -0.016 & -0.092 & -0.106 & 0.092 & $0.149 *$ & $0.214^{*}$ & -0.071 & -0.054 & $0.449 *$ & 1.000 \\
\hline
\end{tabular}

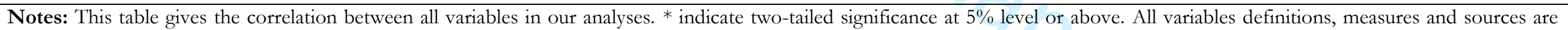
provided in Appendix 1. 
Table 4. Correlation analysis based on annual report and integrated reporting

\begin{tabular}{|c|c|c|c|c|c|c|c|c|c|c|c|c|c|c|}
\hline & (1) & (2) & (3) & (4) & (5) & (6) & (7) & (8) & (9) & (10) & (11) & (12) & (13) & (14) \\
\hline (1) $T R D$ & & $-0.530^{*}$ & $-0.574 *$ & $-0.189 *$ & $0.201 *$ & $-0.255^{*}$ & $0.411 *$ & $-0.212^{*}$ & $-0.191 *$ & $-0.307^{*}$ & -0.039 & $-0.356^{*}$ & -0.092 & -0.101 \\
\hline (2) Price & $-0.549 *$ & & $0.562^{*}$ & $0.270^{*}$ & $-0.201 *$ & $0.266^{*}$ & $-0.302^{*}$ & $0.319^{*}$ & 0.032 & $0.434^{*}$ & -0.036 & $0.207^{*}$ & 0.130 & 0.143 \\
\hline (3) Firm size & $-0.630^{*}$ & $0.612^{*}$ & & -0.028 & $-0.222 *$ & $0.190^{*}$ & $-0.474^{*}$ & 0.065 & $0.434^{*}$ & $0.484^{*}$ & -0.121 & $0.387^{*}$ & $0.265^{*}$ & $0.306^{*}$ \\
\hline (4) Profitability & -0.071 & 0.022 & 0.031 & & -0.096 & $0.170^{*}$ & $-0.368^{*}$ & $0.736^{*}$ & $-0.177^{*}$ & -0.075 & -0.080 & $-0.151 *$ & 0.092 & 0.100 \\
\hline (5) Liquidity & $0.263^{*}$ & -0.157 & $-0.279 *$ & -0.090 & & $-0.291 *$ & 0.130 & $-0.241 *$ & 0.047 & -0.118 & 0.038 & 0.012 & $-0.168^{*}$ & -0.005 \\
\hline (6) Leverage & -0.075 & -0.038 & 0.089 & 0.065 & $-0.290 *$ & & $-0.154^{*}$ & $0.475^{*}$ & -0.106 & $0.167^{*}$ & -0.028 & 0.117 & 0.029 & -0.090 \\
\hline (7) Firm risk & $0.321 *$ & $-0.185^{*}$ & $-0.486^{*}$ & $-0.463 *$ & 0.111 & 0.019 & & $-0.416^{*}$ & $-0.198^{*}$ & $-0.253^{*}$ & 0.014 & $-0.203^{*}$ & $-0.203^{*}$ & -0.049 \\
\hline (8) Market to book & -0.072 & 0.111 & -0.057 & $0.345^{*}$ & -0.161 & $0.248^{*}$ & $-0.283 *$ & & -0.095 & $0.167 *$ & -0.064 & 0.001 & 0.104 & 0.082 \\
\hline (9) Board size & -0.107 & 0.158 & $0.455^{*}$ & -0.022 & -0.043 & 0.037 & $-0.272^{*}$ & -0.033 & & 0.006 & -0.022 & $0.320^{*}$ & 0.069 & $0.151^{*}$ \\
\hline (10) Board independence & $-0.248^{*}$ & $0.291 *$ & $0.474^{*}$ & 0.107 & -0.141 & -0.005 & $-0.316^{*}$ & $0.216^{*}$ & 0.085 & & -0.099 & $0.291 *$ & $0.392^{*}$ & $0.225^{*}$ \\
\hline (11) Duality & -0.088 & -0.051 & 0.080 & -0.013 & -0.114 & 0.017 & -0.078 & 0.060 & 0.031 & -0.104 & & -0.065 & 0.018 & $-0.225^{*}$ \\
\hline $\begin{array}{l}\text { (12) Audit committee size } \\
\text { (13) Audit committee }\end{array}$ & $-0.312^{*}$ & $0.230^{*}$ & $0.305^{*}$ & -0.023 & -0.064 & 0.094 & -0.004 & 0.133 & $0.215^{*}$ & $0.303^{*}$ & 0.110 & & $-0.165^{*}$ & -0.050 \\
\hline independence & $-0.333^{*}$ & $0.240 *$ & $0.387^{*}$ & 0.119 & -0.044 & -0.021 & $-0.520^{*}$ & $0.186^{*}$ & $0.384 *$ & $0.260^{*}$ & 0.057 & -0.143 & & $0.449 *$ \\
\hline (14) Audit quality & $-0.182^{*}$ & 0.163 & $0.306^{*}$ & 0.069 & -0.025 & -0.114 & $-0.227 *$ & 0.123 & 0.147 & $0.213^{*}$ & 0.038 & -0.058 & $0.482^{*}$ & \\
\hline
\end{tabular}

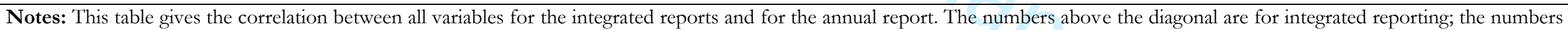
below the diagonal are for annual report. * indicate two-tailed significance at 5\% level or above. All variables definitions, measures and sources are provided in Appendix 1. 


\begin{tabular}{|c|c|c|c|c|}
\hline \multirow[b]{3}{*}{ Variables } & \multicolumn{4}{|c|}{ Dependent variable: $T R D$} \\
\hline & (1) & (2) & (3) & (4) \\
\hline & SA & $\mathrm{UK}$ & All & Diff-in-Diff \\
\hline$I R$ & $\begin{array}{l}-0.147^{* *} \\
(-2.303)\end{array}$ & $\begin{array}{l}0.090^{*} \\
(1.790)\end{array}$ & $\begin{array}{l}0.047 \\
(1.095)\end{array}$ & $\begin{array}{l}0.105^{* *} \\
(2.507)\end{array}$ \\
\hline$S A$ & & & & $\begin{array}{l}0.868^{* * *} \\
(10.404)\end{array}$ \\
\hline$I R^{*} S A$ & & & & $\begin{array}{l}-0.262^{* * *} \\
(-3.316)\end{array}$ \\
\hline Firm size & $\begin{array}{l}0.027 \\
(0.879)\end{array}$ & $\begin{array}{l}0.016 \\
(0.439)\end{array}$ & $\begin{array}{l}0.026 \\
(1.035)\end{array}$ & $\begin{array}{l}0.026 \\
(1.017)\end{array}$ \\
\hline Profitability & $\begin{array}{l}-0.195^{*} \\
(-1.974)\end{array}$ & $\begin{array}{l}-0.043 \\
(-0.526)\end{array}$ & $\begin{array}{l}-0.101 \\
(-1.565)\end{array}$ & $\begin{array}{l}-0.111 \\
(-1.641)\end{array}$ \\
\hline Liquidity & $\begin{array}{l}0.005 \\
(0.358)\end{array}$ & $\begin{array}{l}0.034 \\
(1.258)\end{array}$ & $\begin{array}{l}0.005 \\
(0.370)\end{array}$ & $\begin{array}{l}0.004 \\
(0.338)\end{array}$ \\
\hline Leverage & $\begin{array}{l}-0.035^{* *} \\
(-2.336)\end{array}$ & $\begin{array}{l}0.009 \\
(1.068)\end{array}$ & $\begin{array}{l}-0.008 \\
(-0.818)\end{array}$ & $\begin{array}{l}-0.009 \\
(-0.941)\end{array}$ \\
\hline Firm risk & $\begin{array}{l}-0.104 \\
(-0.546)\end{array}$ & $\begin{array}{l}-0.251 \\
(-0.690)\end{array}$ & $\begin{array}{l}0.006 \\
(0.035)\end{array}$ & $\begin{array}{l}-0.012 \\
(-0.070)\end{array}$ \\
\hline Board size & $\begin{array}{l}-0.403^{* * *} \\
(-2.826)\end{array}$ & $\begin{array}{l}-0.207 \\
(-1.505)\end{array}$ & $\begin{array}{l}-0.349 * * * \\
(-2.996)\end{array}$ & $\begin{array}{l}-0.366^{* * *} \\
(-3.161)\end{array}$ \\
\hline Board independence & $\begin{array}{l}0.174 \\
(0.900)\end{array}$ & $\begin{array}{l}0.021 \\
(0.113)\end{array}$ & $\begin{array}{l}0.063 \\
(0.435)\end{array}$ & $\begin{array}{l}0.049 \\
(0.336)\end{array}$ \\
\hline Duality & $\begin{array}{l}-0.151 \\
(-0.850)\end{array}$ & $\begin{array}{l}-0.130 * * \\
(-2.370)\end{array}$ & $\begin{array}{l}-0.132 \\
(-1.489)\end{array}$ & $\begin{array}{l}-0.114 \\
(-1.322)\end{array}$ \\
\hline Audit committee size & $\begin{array}{l}-0.192 \\
(-1.586)\end{array}$ & $\begin{array}{l}0.025 \\
(0.304)\end{array}$ & $\begin{array}{l}-0.140 \\
(-1.549)\end{array}$ & $\begin{array}{l}-0.138 \\
(-1.522)\end{array}$ \\
\hline Audit committee independence & $\begin{array}{l}-0.109 \\
(-0.565)\end{array}$ & & $\begin{array}{l}-0.043 \\
(-0.283)\end{array}$ & $\begin{array}{l}-0.011 \\
(-0.074)\end{array}$ \\
\hline Audit quality & $\begin{array}{l}-0.073 \\
(-0.692)\end{array}$ & $\begin{array}{l}0.110^{* *} \\
(2.208)\end{array}$ & $\begin{array}{l}-0.039 \\
(-0.460)\end{array}$ & $\begin{array}{l}-0.037 \\
(-0.423)\end{array}$ \\
\hline Year FE & Yes & Yes & Yes & Yes \\
\hline $\begin{array}{l}\text { Industry FE } \\
\text { Country FE }\end{array}$ & Yes & Yes & Yes & Yes \\
\hline Constant & $\begin{array}{l}3.059 * * * \\
(8.205)\end{array}$ & $\begin{array}{l}0.992^{* *} \\
(2.088)\end{array}$ & $\begin{array}{l}\text { yes } \\
1.806 * * * \\
(4.980)\end{array}$ & $\begin{array}{l}1.771 * * * \\
(4.887)\end{array}$ \\
\hline Observations & 215 & 116 & 331 & 331 \\
\hline Adj. R-squared & 0.352 & 0.090 & 0.708 & 0.718 \\
\hline
\end{tabular}

Notes: This table gives the coefficient estimates from ordinary least squares (OLS) regressions testing $\mathrm{H} 1$ on the relationship between adopting integrated reporting and the level of textual risk disclosure. IR is a dummy variable takes a value of 1 in integrated reporting period and 0 otherwise (i.e., annual report period). SA is a dummy variable takes a value of 1 in South Africa mandatory integrating reporting system and 0 otherwise (i.e., in the UK voluntary integrating reporting system). Model 1, 2, 3, and 4 denote OLS estimation in South Africa, the UK, both countries, and difference in differences between both countries, respectively. In Models 1-3, IR capturing the impact of integrated reporting is our main variable of interest. In Model 4, the interaction of IR*SA capturing the impact of mandatory adoption of integrated reporting in South Africa (relative to the voluntary adoption in the UK) is our main variable of interest. T-values are clustered at the firm level and reported in parentheses. *, ** and *** indicate significance for two-tailed tests at the $0.1,0.05$, and 0.01 significance levels, respectively. All continuous variables are winsorized at $1 \%$ on both tails. All variables definitions, measures and sources are provided in Appendix 1. 
Table 6. OLS results for the impact of textual risk disclosure on firm value under integrated reporting context

\begin{tabular}{|c|c|c|c|}
\hline & \multicolumn{3}{|c|}{ Dependent variable: Firm's share price } \\
\hline & $(1)$ & (2) & (3) \\
\hline Variables & All & SA & UK \\
\hline \multirow[t]{2}{*}{$T R D$} & $0.500^{*}$ & 0.024 & 0.369 \\
\hline & $(1.857)$ & $(1.161)$ & $(0.367)$ \\
\hline \multirow[t]{2}{*}{$I R$} & 0.528 & -0.026 & 0.631 \\
\hline & $(1.318)$ & $(-0.490)$ & $(0.333)$ \\
\hline \multirow[t]{2}{*}{$I R * T R D$} & -0.025 & 0.012 & -0.312 \\
\hline & $(-0.125)$ & $(0.386)$ & $(-0.150)$ \\
\hline \multirow[t]{2}{*}{ Firm size } & $0.135^{* *}$ & 0.003 & 0.291 \\
\hline & $(2.028)$ & $(0.629)$ & $(1.381)$ \\
\hline \multirow[t]{2}{*}{ Profitability } & $0.524^{*}$ & 0.003 & $1.527 * *$ \\
\hline & $(1.873)$ & $(0.237)$ & $(2.140)$ \\
\hline \multirow[t]{2}{*}{ Liquidity } & 0.047 & -0.000 & 0.077 \\
\hline & $(1.088)$ & $(-0.118)$ & $(0.429)$ \\
\hline \multirow[t]{2}{*}{ Leverage } & -0.023 & $-0.007 * *$ & -0.022 \\
\hline & $(-0.554)$ & $(-2.029)$ & $(-0.356)$ \\
\hline \multirow[t]{2}{*}{ Firm risk } & $1.462^{* * *}$ & -0.065 & $3.829 * * *$ \\
\hline & $(2.853)$ & $(-1.375)$ & $(2.946)$ \\
\hline \multirow[t]{2}{*}{ Market to book } & $0.088^{* *}$ & $0.008^{* *}$ & $0.147^{*}$ \\
\hline & $(2.530)$ & $(2.520)$ & (1.864) \\
\hline \multirow[t]{2}{*}{ Board size } & $0.531 *$ & 0.023 & 1.006 \\
\hline & $(1.921)$ & $(0.669)$ & $(1.320)$ \\
\hline \multirow[t]{2}{*}{ Board independence } & 0.300 & 0.008 & 1.075 \\
\hline & $(0.713)$ & $(0.151)$ & $(0.840)$ \\
\hline \multirow[t]{2}{*}{ Duality } & -0.249 & -0.012 & $-0.705^{* *}$ \\
\hline & $(-0.920)$ & $(-0.640)$ & $(-2.172)$ \\
\hline \multirow[t]{2}{*}{ Audit committee size } & -0.297 & 0.024 & -0.006 \\
\hline & $(-1.050)$ & $(0.989)$ & $(-0.012)$ \\
\hline \multirow[t]{2}{*}{ Audit committee independence } & -0.206 & 0.018 & \\
\hline & $(-0.476)$ & $(0.451)$ & \\
\hline \multirow[t]{2}{*}{ Audit quality } & -0.188 & 0.020 & 0.135 \\
\hline & $(-0.814)$ & $(1.462)$ & $(0.258)$ \\
\hline Year FE & Yes & Yes & Yes \\
\hline Industry FE & Yes & Yes & Yes \\
\hline Country FE & Yes & & \\
\hline \multirow[t]{2}{*}{ Constant } & $-3.420 * *$ & -0.148 & $-9.910^{* * *}$ \\
\hline & $(-2.443)$ & $(-1.118)$ & $(-4.443)$ \\
\hline Observations & 294 & 190 & 104 \\
\hline Adj. R-squared & 0.543 & 0.389 & 0.445 \\
\hline
\end{tabular}

Notes: This table gives the coefficient estimates from ordinary least squares (OLS) regressions testing $\mathrm{H} 2$ on the impact of textual risk disclosure on firm's market value considering integrated reporting context. IR is a dummy variable takes a value of 1 in integrated reporting period and 0 otherwise (i.e., annual report period). Model 1, 2, and 3 denote OLS estimation of All (i.e., South Africa and the UK), South Africa, and the UK samples, respectively. In these Models, the interaction of IR*TRD capturing the impact of textual risk disclosure on the firm's market value under the integrated reporting context (relative to the conventional annual report context) is our main variable of interest. T-values are clustered at the firm level and reported in parentheses. *, ** and *** indicate significance for two-tailed tests at the $0.1,0.05$, and 0.01 significance levels, respectively. All continuous variables are winsorized at $1 \%$ on both tails. All variables definitions, measures and sources are provided in Appendix 1. 


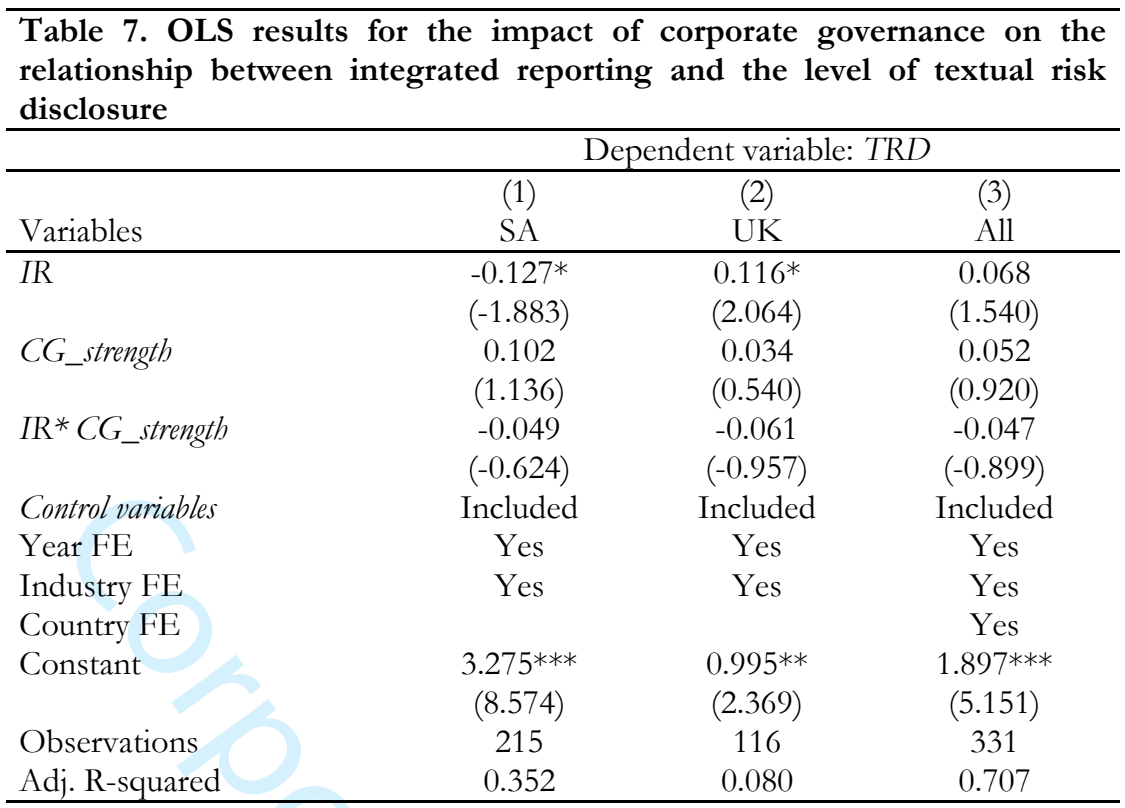

Notes: This table gives the coefficient estimates from ordinary least squares (OLS) regressions testing whether corporate governance moderates the relationship between the integrated reporting and the level of textual risk disclosure. IR is a dummy variable takes a value of 1 in integrated reporting period and 0 otherwise (i.e., annual report period). CG_strength is a dummy variable, capturing the firm's corporate governance environment, that takes the value of 1 if the firm's corporate governance summary is greater than the sample median and 0 otherwise. In this respect, we construct a CG summary measure that is equal to the sum of the study's six corporate governance variables (see table 1). Each governance continuous variable is turned into a dichotomous variable takes the value of 1 if it is greater than the sample median and 0 otherwise. (e.g., DeFond and Francis 2005). Model 1, 2, and 3 denote OLS estimation in South Africa, the $\mathrm{UK}$, and both countries, respectively. In these Models, the interaction of IR*CG_strength capturing the moderating effect of firm's corporate governance environment on the relationship between integrated reporting system and the level of textual risk disclosure is our main variable of interest. T-values are clustered at the firm level and reported in parentheses. ${ }^{*}, * *$ and $* * *$ indicate significance for two-tailed tests at the $0.1,0.05$, and 0.01 significance levels, respectively. All continuous variables are winsorized at $1 \%$ on both tails. All variables definitions, measures and sources are provided in Appendix 1. 
Table 8. Cross-sectional OLS results for the impact of textual risk disclosure on firm value under different reporting contexts

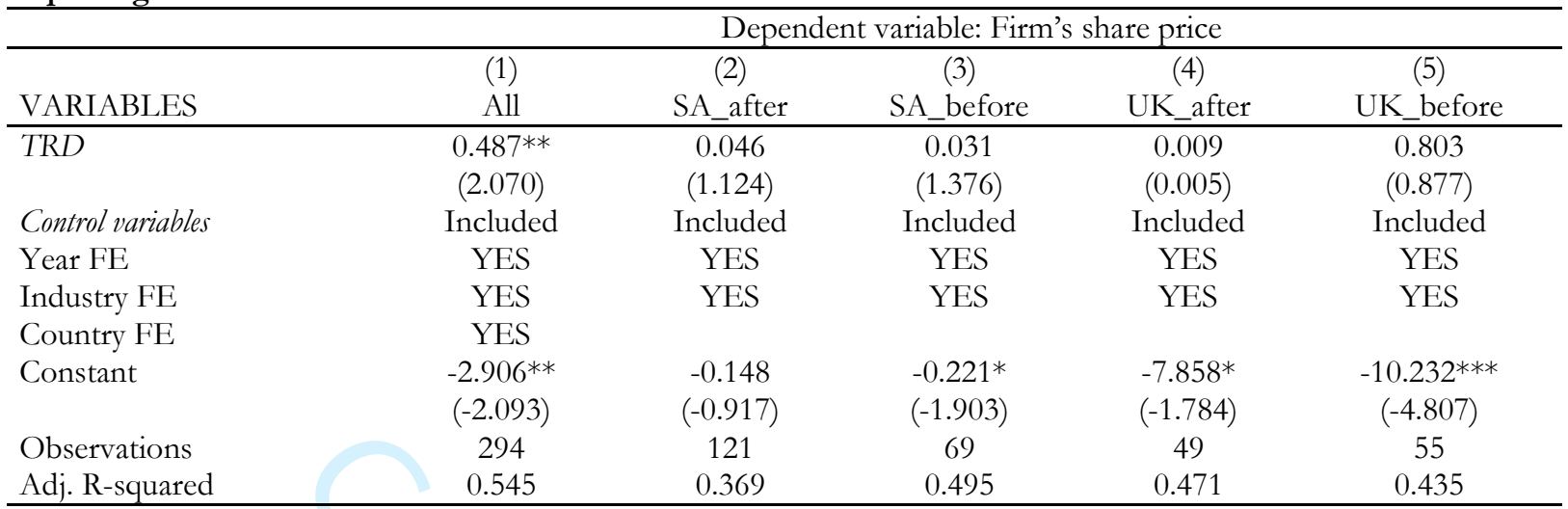

Notes: This table gives the coefficient estimates from ordinary least squares (OLS) regressions that show the crosssectional analyses of the impact of textual risk disclosure on firm's market value. All denotes to the estimation employing all the sample (i.e., South Africa and the UK). SA_after and SA_before denoting the estimation employing South Africa sample under the mandatory integrated reporting and the conventional annual report, respectively. UK_after and UK_before denoting the estimation employing the UK voluntary integrating reporting setting during the corresponding periods. T-values are clustered at the firm level and reported in parentheses. *, ** and *** indicate significance for twotailed tests at the $0.1,0.05$, and 0.01 significance levels, respectively. All continuous variables are winsorized at $1 \%$ on both tails. All variables definitions, measures and sources are provided in Appendix 1. 


\section{Appendix 1. Variable definitions, measures, sources, and sample of relevant literature}

\begin{tabular}{|c|c|c|c|}
\hline $4^{3}$ ariable & Definitions and measures & Source & Sample of relevant literature \\
\hline $\begin{array}{l}\text { TRD }(\%) \\
6 \\
7 \\
8\end{array}$ & $\begin{array}{l}\text { Textual Risk Disclosure measured by the } \% \text { of words } \\
\text { indicating risk based on risk-word list. }\end{array}$ & $\begin{array}{l}\text { Annual and } \\
\text { Integrated reports/ } \\
\text { Textual analysis }\end{array}$ & $\begin{array}{l}\text { (e.g., Elshandidy et al., 2013; Elshandidy et al., } \\
\text { 2015; Elshandidy and Neri, 2015; Elshandidy } \\
\text { and Shrives, 2016) }\end{array}$ \\
\hline $\begin{array}{l}\text { 9Price } \\
10 \\
11\end{array}$ & $\begin{array}{l}\text { Calculated as the average of firm's share price during the } \\
\text { three months after the release of annual report and } \\
\text { integrated reporting. }\end{array}$ & Datastream & $\begin{array}{l}\text { (e.g., Hassan et al., 2009; Campbell et al., 2014; } \\
\text { Nekhili et al., 2016) }\end{array}$ \\
\hline $\begin{array}{l}12 \\
\text { Figrm size }\end{array}$ & Captured by the log of total assets. & Datastream & (e.g., Barako et al., 2006) \\
\hline $\begin{array}{l}\text { Profitability } \\
15\end{array}$ & Captured by the return on equity. & Datastream & (e.g., Elshandidy et al., 2013) \\
\hline 16quidity & Captured by the current ratio. & Datastream & (e.g., Elshandidy et al., 2013) \\
\hline $\begin{array}{l}17 \\
18 \text { verage }\end{array}$ & Measured by the ratio of total debt to total equity. & Datastream & (e.g., Elshandidy et al., 2013) \\
\hline $\begin{array}{l}19 \text { rm risk } \\
20\end{array}$ & Captured by volatilit & Datastream & (e.g., Elshandidy et al., 2013) \\
\hline $\begin{array}{l}21 \text { arket to book } \\
22\end{array}$ & Measured by market value of equity/total equity. & Datastream & $\begin{array}{l}\text { (e.g., Campbell et al., 2014; Elshandidy \& } \\
\text { Shrives, 2016) }\end{array}$ \\
\hline $\begin{array}{l}23 \\
\text { B4ard size } \\
25 \\
26\end{array}$ & $\begin{array}{l}\text { Measured by the log of the total number of directors on } \\
\text { the board. }\end{array}$ & Manually collected & $\begin{array}{l}\text { (e.g., DeFond and Francis, 2005; Li et al., } \\
\text { 2012; Elshandidy et al., 2013; Elshandidy and } \\
\text { Neri, 2015) }\end{array}$ \\
\hline $\begin{array}{l}27 \\
28 \text { ard independence } \\
29 \\
30\end{array}$ & $\begin{array}{l}\text { Measured by the percentage of independent directors on } \\
\text { the board. }\end{array}$ & Manually collected & $\begin{array}{l}\text { (e.g., DeFond and Francis, 2005; Li et al., } \\
\text { 2012; Elshandidy et al., 2013; Elshandidy and } \\
\text { Neri, 2015) }\end{array}$ \\
\hline $\begin{array}{l}31 \text { uality } \\
32 \\
33 \\
34\end{array}$ & $\begin{array}{l}\text { Measured as a dummy variable, which takes the value } 1 \text { if } \\
\text { the role of } C E O \text { and the chairman of the board is the same } \\
\text { person and } 0 \text { otherwise. }\end{array}$ & Manually collected & $\begin{array}{l}\text { (e.g., DeFond and Francis, 2005; Li et al., } \\
\text { 2012; Elshandidy et al., 2013; Elshandidy and } \\
\text { Neri, 2015) }\end{array}$ \\
\hline 35 udit committee size & $\begin{array}{l}\text { Measured by the log of the number of directors of the } \\
\text { audit committee. }\end{array}$ & Manually collected & (e.g., Kent and Stewart, 2008; Li et al., 2012) \\
\hline $\begin{array}{l}37 \text { committee } \\
38 \text { dit } \\
\text { 36dependence }\end{array}$ & $\begin{array}{l}\text { Measured by proportion of independent directors of the } \\
\text { audit committee. }\end{array}$ & Manually collected & (e.g., Kent and Stewart, 2008; Li et al., 2012) \\
\hline $\begin{array}{l}49 \text { udit quality } \\
41 \\
42 \\
43\end{array}$ & $\begin{array}{l}\text { Measured as a dummy variable, which takes the value } 1 \text { if } \\
\text { the external auditor of the company is one of the "big } \\
\text { four" and } 0 \text { otherwise. }\end{array}$ & Manually collected & $\begin{array}{l}\text { (e.g., Elshandidy et al., 2013; Elshandidy and } \\
\text { Neri, 2015) }\end{array}$ \\
\hline
\end{tabular}

Alotes: This appendix provides the variable definitions, measures, sources, and sample of relevant literature.

\section{5}

